४

\title{
SESIÓN LÚDICA SOBRE LA IMPORTANCIA DE LA SALUD ORAL
}

Por: Jenny Paola Salamanca ${ }^{+++\dagger}$

El primer grupo de estudiantes de Medicina de 90 semestre de la rotación de Escolares en Pediatría

Comunitaria, preparó y llevó a cabo una sesión lúdica sobre la importancia de la salud oral en la

edad escolar. A través del taller que se realizó con los niños de primer grado de primaria en el colegio Gonzalo Arango, se les enseñaron los mejores hábitos de salud oral, incluyendo el cepillado y

el uso de la seda dental. Cerca de 40 niños y niñas del colegio recibieron por parte de los estudiantes un kit de salud oral compuesto por cepillo de dientes, vaso plástico, crema dental, seda dental y un pequeño detalle para niños y niñas.

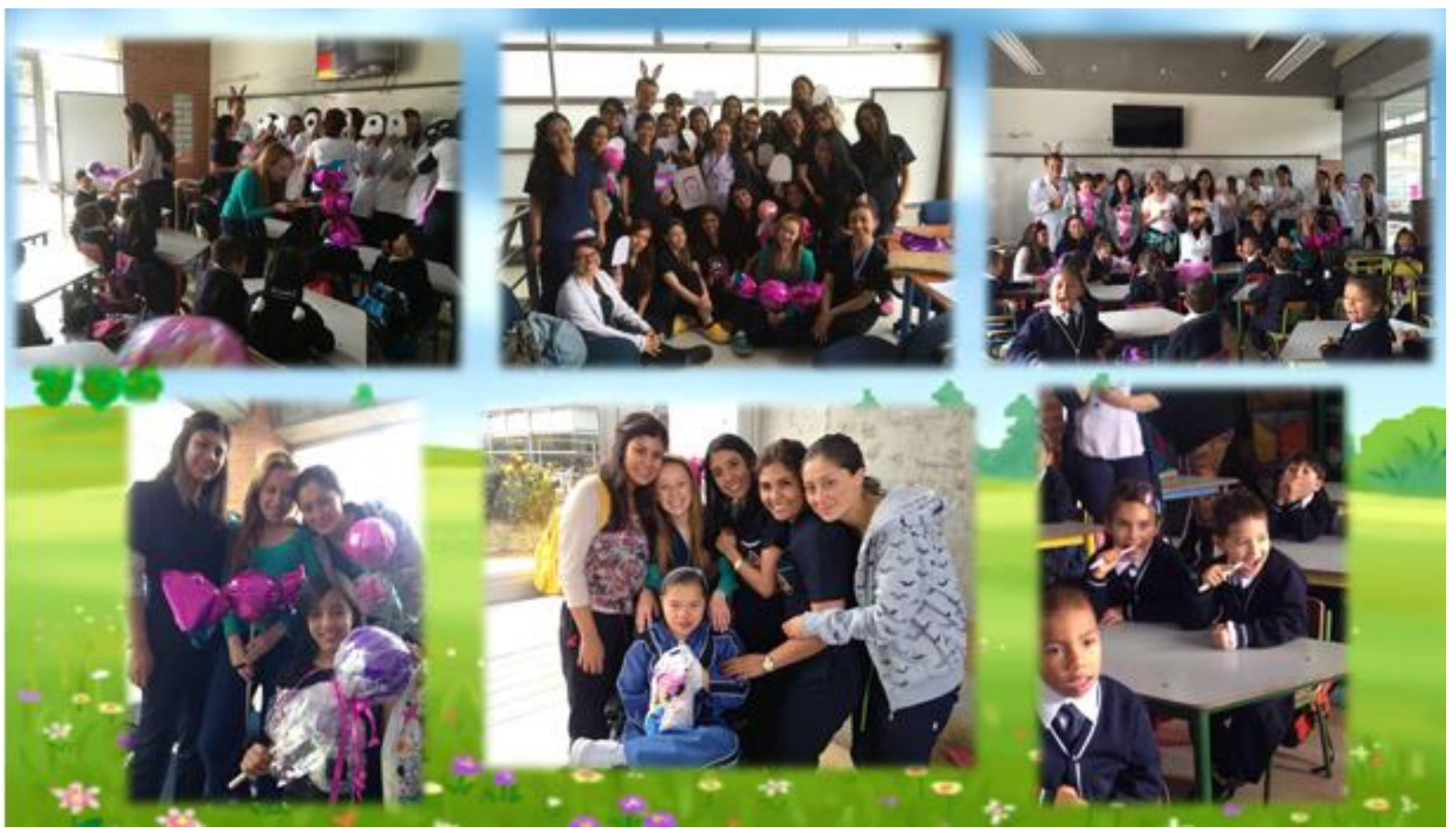

¡Corpas presente en la comunidad!

${ }^{+++++}$MD, Docente FUJNC - jenny-salamanca@juanncorpas.edu.co

Carta Comunitaria. Vol. 24. Número 137. Marzo - Abril 2016 